\title{
TREATMENT OF PERIPROSTHETIC FEMORAL FRACTURES AFTER TOTAL HIP ARTHROPLASTY VANCOUVER TYPE B
}

\author{
Nikola Bulatović , Miroslav Kezunović $^{1}$, Čedomir Vučetić ${ }^{2}$, Nermin Abdić ${ }^{1}$ \\ Ivan Benčić ${ }^{3}$ and Tomislav Čengić ${ }^{3,4}$
}

${ }^{1}$ Clinical Center of Montenegro, Clinical Department of Orthopedic Surgery and Traumatology, Podgorica, Montenegro; ${ }^{2}$ Clinical Center of Serbia, Clinical Department of Orthopedic Surgery and Traumatology, Belgrade, Serbia; ${ }^{3}$ Sestre milosrdnice University Hospital Center, Clinical Department of Traumatology, Zagreb, Croatia; ${ }^{4}$ University of Applied Health Sciences, Zagreb, Croatia

SUMMARY - The rate of periprosthetic femoral fractures following total hip replacement has been growing steadily in the last 20 years and ranges from $0.1 \%$ to $2.1 \%$. These fractures are mostly related to older patients with the presence of chronic diseases and frequently poor bone quality. The treatment is surgically very complex and demanding, followed by a series of complications. The evaluation in this retrospective study included 23 patients who were medically treated from January 2004 to December 2015 with the mean follow-up of 14.5 (range, 9-25) months. There were 17 patients with cement total hip arthroplasty (THA) and 6 with cementless THA. During treatment of fractures, different techniques were implemented including the use of wire cerclage, dynamic compression plates (DCP), a locking compression plate (LCP) system, and long revision stem. For the purpose of distinguishing fractures, we used the Vancouver classification by Duncan and Masri. For clinical evaluation, we used the modified Merle d'Aubigné score system and monitored complications during treatment. The aim is to show treatment results of the type B periprosthetic femoral fractures by using different operative treatment techniques. According to the Vancouver classification within type B, 10 (43.47\%) patients had type B1 fractures, another 10 (43.47\%) patients had type B2 fractures, and three (13.04\%) patients had type B3 fractures. According to gender distribution, there were eight (34.8\%) male and 15 (65.2\%) female patients, mean age 59.5 (range, 47-86) years. Twelve (52.2\%) and 11 (47.8\%) patients had left- and right-sided fractures, respectively. The mean length of hospital stay was 16 (range, 9-26) days. According to the Merle d'Aubigné score system, 10 patients with type B1 fractures had the mean score of 11.5 points, which is poor result. Poor result was also recorded in patients with type B2 fractures, with the mean score of 10.6 points. The three patients with type B3 fractures had the mean score of 12 points, which is considered fair score. In conclusion, Vancouver classification has been widely accepted and using the protocols makes decision making during treatment much easier. During treatment of this type of fracture, we used various implants, wire cerclage, DCP and LCP, as well as long stem revision. In certain cases, we applied surgical techniques, implants that are not recommended by the Vancouver protocol by which we treated periprosthetic femoral fractures; in these case, we recorded nonunion bone, malunion and breaking of implants, which resulted in poor treatment outcome.

Key words: Total hip arthroplasty; Periprosthetic femoral fractures; Vancouver classification; Complications

Correspondence to: Nikola Bulatovic, $M D, M S$, Clinical Center of Montenegro, Clinical Department of Orthopedic Surgery and Traumatology, Ljubljanska bb, 81000 Podgorica, Montenegro

Received July 18, 2017, accepted September 1, 2017 


\section{Introduction}

Periprosthetic femoral fractures after total hip replacement have been increasing in the last 2-3 decades, most likely due to expansion of the indication and an increased number of the prostheses implanted. A periprosthetic femoral fracture followed by total hip replacement was originally published in 1954.

The rate of periprosthetic femoral fractures ranges from $0.1 \%$ to $2.1 \%$ depending on the author and timing of publication. According to data from the Mayo Clinic Joint Registry, the rate of periprosthetic femoral fracture after primary total hip arthroplasty (THA) was $1.1 \%$ and it was $4.0 \%$ after revision of THA $^{1}$. Kavanagh $^{2}$ estimated the rate to be $1 \%$ after primary THA and $4.2 \%$ after revision of THA. Lowenhielm et $a l^{3}$ found the annual incidence to be unevenly distributed, ranging between $0 \%$ and $1.2 \%$ during the 15-year study period.

The predisposing factors for periprosthetic femoral fractures are age, gender, inflammatory arthropathy, metabolic diseases, osteoporosis, biomechanical problems, osteolysis and aseptic loosening, and surgical techniques ${ }^{4}$. The most common mechanism of the occurrence of these fractures is the effect of low kinetic energy force. The fractures can occur in case of fall on a flat surface during movement or in the house during everyday activities.

At the beginning, the treatment was nonoperative with skeletal traction and plaster immobilization. Today, nonoperative treatment is usually applied in case of non-dislocated fractures in old patients at a high risk of surgical treatment due to associated chronic diseases or some other reasons that make them not eligible to surgical treatment.

The current trend for periprosthetic femoral fractures is surgical treatment. There are protocols that direct the mode of treatment and choice of implants depending on the type of periprosthetic treatment. Surgical treatment of these injuries is very complex and followed by various complications, sometimes even with fatal outcome. Patients with these fractures are mostly elderly people with poor bone quality and presence of chronic diseases. Configuration of the fracture is often followed by biomechanical problems and loosening of implants. Treatment of periprosthetic fractures includes Open Reduction and Internal Fixation (ORIF) with plate, wire cerclage, bone graft, and stem revision prosthesis ${ }^{5}$.
Duncan and Masri developed a system of classification of periprosthetic fractures according to location, implant stability, and degree of bone loss, known as Vancouver classification ${ }^{6}$, with 3 types (A, B and C), and advocated an algorithm for treatment.

\section{Materials and Methods}

In this retrospective study, we focused on postoperative periprosthetic femoral fractures treated in our Department from January 2004 until December 2015. The following were not included in the study group: periprosthetic acetabular fractures, intraoperative and conservatively treated femoral fractures. In total, we evaluated 23 periprosthetic fractures in 23 patients.

Patients were evaluated with respect to gender, side of injury, age, time of hospitalization, time to union and complications (nonunion and malunion-refractures, deep vein thrombosis, infection and osteitis, and pressure ulcers on the skin). The mean follow-up was 14.5 (range, 9-25) months. There were 17 patients with cement THA, five with cementless THA, and one patient with a hybrid type prosthesis.

When we divided the patients into groups by the Vancouver classification, we evaluated their preoperative radiographs. Type B fractures occur at the type of the stem or just distal to it. The category is divided further on the basis of the stem stability and quality of the remaining proximal femoral bone stock. In type B1 fractures, the stem remains well fixed, and in type B2 fractures, the stem is loose. In type B3 fractures, the stem is loose, and the proximal femur is deficient because of osteolysis, osteoporosis, or fracture comminution ${ }^{6}$.

If radiolucent zones around the stem is wider than 2-3 $\mathrm{mm}$, we believe that the femoral component is loose, and break lines indicate the released stem and zones around cement mass in the femur, as described by Gruen in his classification consisting of 14 zones $^{7}$. According to Park et al. ${ }^{8}$, fracture union is defined clinically as the ability to bear weight fully with or without aids and evidence of tricortical callus bridging fracture on anteroposterior and lateral radiographs.

Clinical evaluations were performed using the Modified Merle d'Aubigné score system ${ }^{9}$.

The following comorbidities present in study patients were considered to significantly affect patient 


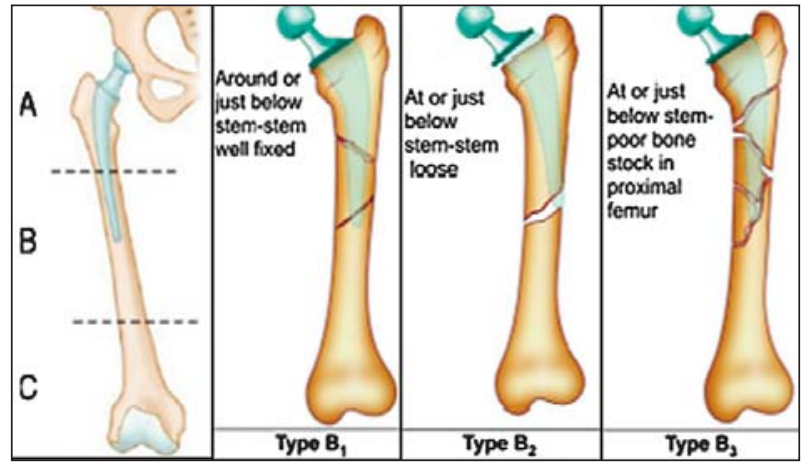

Fig. 1. Vancouver classification of postoperative periprosthetic femur fractures type $B^{6}$.

\begin{tabular}{|ll|}
\hline Modified Merle d'Aubigne Scale & \\
Criteria & Points \\
Pain & \\
None & 6 \\
Slight or intermittent & 5 \\
After walking but resolves & 4 \\
Moderately severe but patient is able to walk & 3 \\
Severe, prevents walking & 2 \\
Walking & \\
Normal & 6 \\
No cane but slight limp & 5 \\
Long distance with cane or crutch & 4 \\
Limited even with support & 3 \\
Very limited & 2 \\
Unable to walk & 1 \\
Range of motion & \\
$95-100 \%$ & 6 \\
$80-94 \%$ & 5 \\
$70-79 \%$ & 4 \\
60-69\% & 3 \\
50-59\% & 2 \\
<50\% & 1 \\
Clinical grade & \\
Excellent & 18 \\
Good & 15,16, or 17 \\
Fair & 13 to 14 \\
Poor & $<13$ \\
\hline
\end{tabular}

Fig. 2. Modified Merle d'Aubigné score system?.

mobility: group of neuromuscular disorders, including Parkinson's disease, multiple sclerosis, and post-stroke condition in one patient each.

\section{Results}

We evaluated 23 periprosthetic fractures in $23 \mathrm{pa}^{-}$ tients operated on between January 2004 and December 2015. There were 8 (34.8\%) male and 15 (65.2\%) female patients. Out of all Vancouver type B fractures, there were 10 (43.47\%) patients with B1 type fractures with 8 cemented and 2 cementless prostheses, 10 (43.47\%) patients with B2 type fractures with 7 cemented and 3 cementless prostheses, and three (13.04\%) patients with B3 type fractures with 2 cemented prostheses and 1 hybrid prosthesis (cemented stem). The mean age of patients was 59.9 (47-86) years. There were $12(52.2 \%)$ patients with left-sided fracture and 11 (47.8\%) patients with right-sided fracture. The mean length of hospital stay was 16 (range, 9-26) days.

In the group of 10 patients with B1 fracture, six patients were treated with the locking compression plate (LCP) system, three patients with dynamic compression plate $(\mathrm{DCP})$, and one patient with multiple wire cerclage. Complications developed in four patients.

The complications that occurred during treatment in this group were as follows: in one case, migration of the materials and fracture of DCP occurred at 6 months after surgery. After that, reosteosynthesis with LCP system was performed. Several weeks later, there were problems in terms of early wound infection and development of pressure ulcer in the sacral region. Due to these problems, incision and debridement of wounds had to be performed using negative-pressure wound therapy and antibiotic therapy after smear analysis. Complications were eliminated with antidecubitus therapy and local therapy. In another case, LCP breaking occurred 4 months after surgery. Reoperation was performed, cement stem was removed and long cementless stem was reimplanted. In case with multiple cerclage wires, there were pressure ulcers on the skin.

In another case of LCP fixation, periprosthetic fractures appeared. We treated wound infection with surgical debridement, local care and antibiotics for several weeks until wound healing. According to Mer-

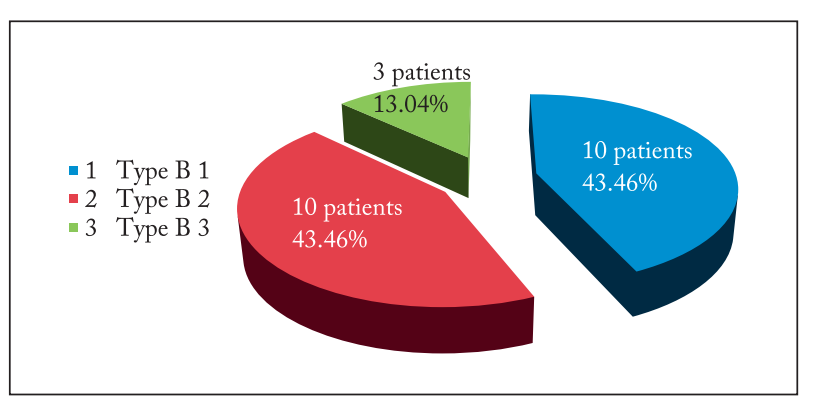

Fig. 3. Distribution of type B fractures in study patients. 
A)

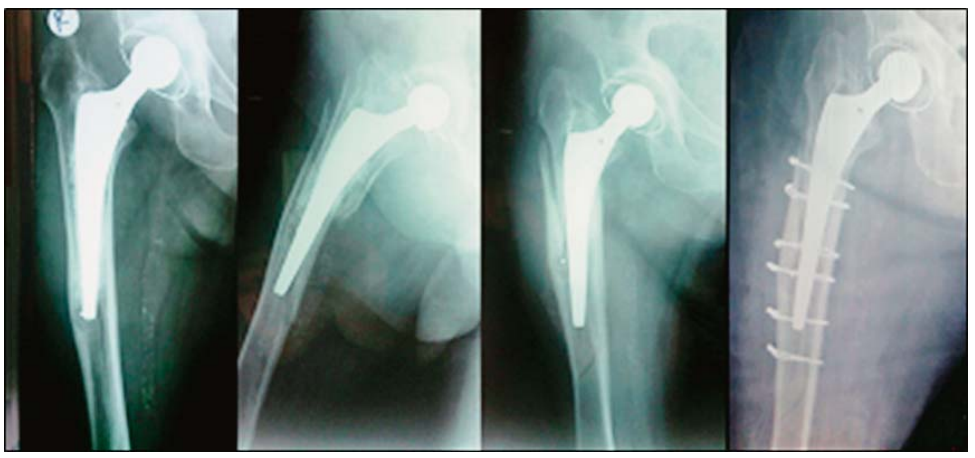

B)

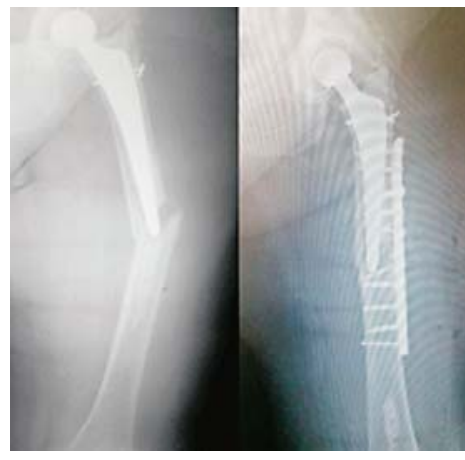

Fig. 4. Type B1 periprosthetic femur fractures: (A) by multiple cerclage wires; and (B) dynamic compression plate.

\begin{tabular}{|c|c|c|c|c|c|c|}
\hline $\begin{array}{l}\text { Types } \text { Of } \\
\text { fracture }\end{array}$ & $\begin{array}{l}\text { Number of patients } \\
\text { and fractures }\end{array}$ & Typ of THA & $\begin{array}{l}\text { Number of } \\
\text { patients trea }\end{array}$ & & Complication/number of patients & $\begin{array}{l}\text { Merle d'Aubigné } \\
\text { score (points) }\end{array}$ \\
\hline \multirow{3}{*}{$\mathrm{B}_{1}$} & \multirow{3}{*}{$10 / 10$} & $\begin{array}{l}\text { cementless } 1 \\
\text { cemented } 6\end{array}$ & Lcp & 6 & $\begin{array}{l}\text { superficial wound infection (/1pat.) } \\
\text { broken LCP/ reop.Long stem (/1pat.) }\end{array}$ & \multirow{3}{*}{$\begin{array}{l}11.5 \\
\text { (bad) }\end{array}$} \\
\hline & & $\begin{array}{ll}\text { cementless } & 0 \\
\text { cemented } & 1\end{array}$ & Cerclage & 1 & pressure ulcers on the skin (/1 pat.) & \\
\hline & & $\begin{array}{ll}\text { cementless } 1 \\
\text { cemented }\end{array}$ & DCP & 3 & $\begin{array}{l}\text { migration and broken / reop.LCP/ } \\
\text { infectio wound, pressure ulcers skin (/1pat.) }\end{array}$ & \\
\hline \multirow{4}{*}{$\mathrm{B}_{2}$} & \multirow{4}{*}{$10 / 10$} & $\begin{array}{l}\text { cementless } \\
\text { cemented }\end{array}$ & $\mathrm{LCP}$ & 5 & $\begin{array}{l}\text { broken plate /reop. LCP/ (/1pat.) } \\
\text { pressure ulcers on the skin (/1pat.) } \\
\text { broken LCP/ reop.Long stem(/1pat.) } \\
\text { deep vein thrombosis(/1pat.) }\end{array}$ & \multirow{4}{*}{$\begin{array}{l}10,6 \\
(\text { bad })\end{array}$} \\
\hline & & $\begin{array}{ll}\text { cementless } & 0 \\
\text { cemented } & 1\end{array}$ & Long stem & 1 & & \\
\hline & & $\begin{array}{ll}\text { cementless } & 1 \\
\text { cemented } & 1\end{array}$ & DCP & 2 & $\begin{array}{l}\text { broken plate/reop. Long stem(/1pat.) } \\
\text { superficial wound infection (/1pat.) }\end{array}$ & \\
\hline & & $\begin{array}{ll}\text { cementless } & 0 \\
\text { cemented } & 1\end{array}$ & Cerclage & 1 & wound infection and ulcer on the skin (/1pat) & \\
\hline \multirow{2}{*}{$\mathrm{B}_{3}$} & \multirow{2}{*}{$3 / 3$} & $\begin{array}{l}\text { cementless } 0 \\
\text { cemented } 2\end{array}$ & LCP & 2 & $\begin{array}{l}\text { broken plate /reop. LCP (/1pat.) } \\
\text { superficial wound infection (/1pat.) }\end{array}$ & \multirow{2}{*}{$\begin{array}{l}12.0 \\
\text { (fair) }\end{array}$} \\
\hline & & $\begin{array}{l}\text { cementless } \\
\text { cemented }\end{array}$ & Long stem & 1 & & \\
\hline
\end{tabular}

Fig. 5. The mean Merle d'Aubigné system clinical score, classification of patients, and complications found in particular Vancouver type fractures.

le d'Aubigné, poor result was achieved with a score of 11.5 points.

In the group of Vancouver B2 fractures, we treated one patient with reimplantation of a revision stem, two patients using DCP, five patients with LCP osteofixation, and two patients with multiple wire cerclage. Complications occurred in three patients.

In two cases, there was a break in the LCP system and in one additional case DCP was broken. There was a need to perform reosteosynthesis with LCP in one case and with long cementless stem in the other two cases. In all three cases, patients recovered well. In one patients with LCP system, there were pressure ulcers on the skin which were treated successfully with local care. One patient had deep vein thrombosis in the early postoperative period. It was also successfully treated with continuous heparin therapy.

One patient with multiple wire cerclages who developed superficial wound infection and ulcer on the skin and was moving slowly failed to present for 9-month follow-up, and another patient died after one year of operation.

According to the Merle d'Aubigné scoring system, we achieved poor result of 10.6 points. In the group of Vancouver B3 fractures, we treated two patients with LCP osteosynthesis and one patient with long revision stem implantation. The complications included one case of broken LCP at 3 months after surgery and su- 
perficial wound infection after second surgical intervention. That patient was treated by LCP reosteosynthesis and bone graft. After 3 weeks, wound infection developed and was successfully treated within several weeks by surgical debridement, antibiotics and negative-pressure wound therapy. According to the Merle d'Aubigné system, we achieved fair result of 12 points.

The fracture union rate was $73.91 \%(n=17)$ and reoperation rate $26.08 \%(\mathrm{n}=6)$ without prosthesis dislocation or osteitis.

\section{Discussion}

Treatment of total hip periprosthetic femoral fractures is dependent on a few fracture characteristics such as fracture location, femoral bone stock, implant stability, patient characteristics including age and medical comorbidities, surgeon experience, and disposal of implanted material ${ }^{7,8}$. Most postoperative periprosthetic femoral fractures result from low-energy falls from sitting or standing heights.

In our case, all patients sustained fractures by the influence of low-energy force followed by patient fall. In a series of 71 cases of periprosthetic fractures, $\mathrm{Zu}^{-}$

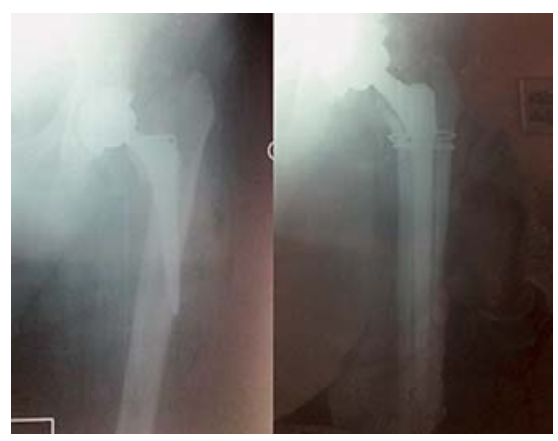

Fig. 6. Type B2 periprosthetic femur fractures managed by long stem and cerclage wires. urmond et al. ${ }^{9}$ recorded minor trauma in 87\%, spontaneous fractures in $9 \%$, and major trauma in $4 \%$ of cases. Chakravarthy et al. ${ }^{10}$ report on 12 cases with well-fixed components, and in all cases the mechanism of injury was low-energy fall.

In recent publications, the authors state that approximately $75 \%$ of periprosthetic fractures around a primary femoral stem are associated with a loose stem. Loosening of the femoral stem is radiographically visible by the presence of radiolucent zones around the stem. It is shown both around cementless and cement stem. In relation to the radiographic evaluation of loosening, we based our work on so-called Gruen scheme which consists of 14 zones in 2 projections of $\mathrm{x}$-rays with cement stem. For significant radiolucent zone, we applied intersurface gap larger than $2 \mathrm{~mm}^{7,11}$.

Treatment of periprosthetic fractures is followed by a lot of complications and failures in the final outcome of treatment. The most common complications are deep venous thrombosis, pneumonia, contractures of the hip and knee with muscle atrophy, pressure ulcers on the skin, nonunion and refractures, and respiratory distress syndrome ${ }^{9,12}$.

Development of surgical techniques has enabled greater success in treatment, which is reflected in faster recovery and less complication rate with better overall score for periprosthetic femoral fracture treatment process. The preferred surgical treatment leads to anatomical position of the fracture, stable fixation and high percentage of healing. Nevertheless, this kind of treatment is also followed by complications, mainly infections and dislocations, material damage, dislocation of prosthesis, and refractures.

Lindahl et al. ${ }^{5}$ report on 1049 patients with the overall complication rate of $18 \%$; of the 245 patients in this group, the most common reasons for reoperation were nonunion $(24 \%)$, refracture (24\%), aseptic loosening (21\%), and recurrent dislocation (16\%).

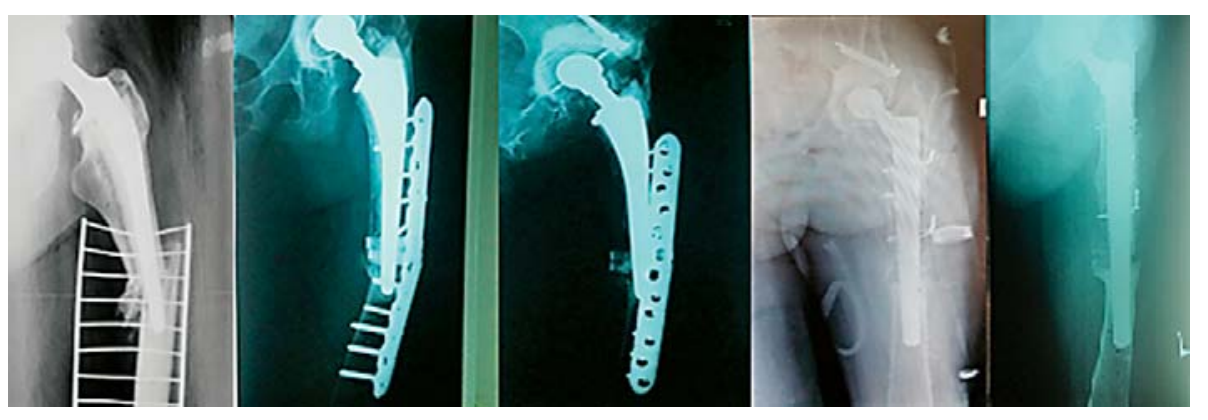

Fig. 7. Type B2 periprosthetic femur refractures with locking compression plate and revision by long stem and cerclage wires. 

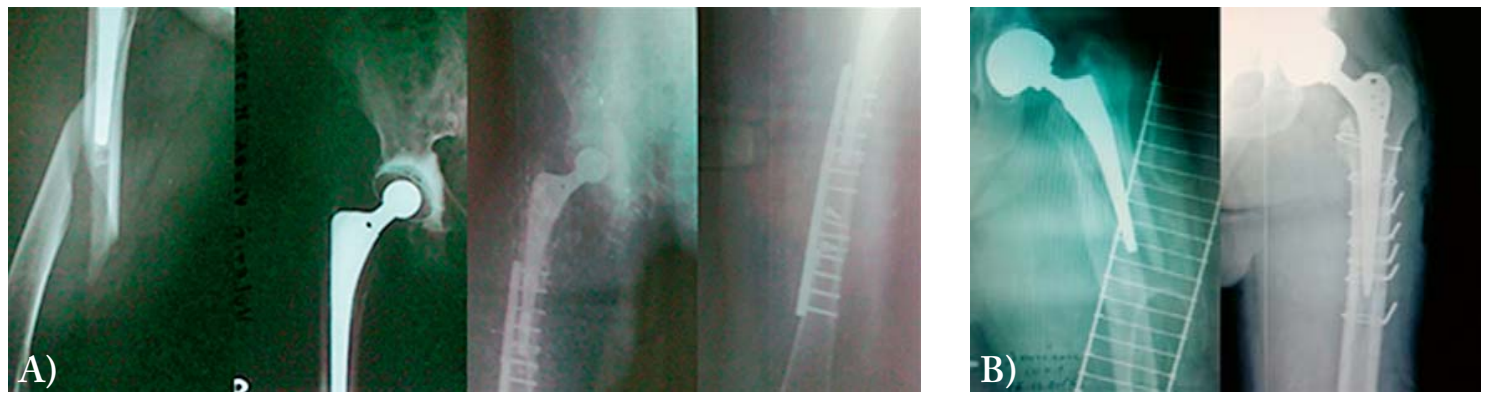

Fig. 8. Type B3 periprosthetic femur fractures: (A) locking compression plate; and (B) long stem with cerclage wires.

In both nonoperative and operative treatments, mortality rate varies among literature reports. In our study, the mortality rate at postoperative 1 -year follow-up was $4.34 \%(n=1)$. In a retrospective study on 106 patients with periprosthetic fracture of the femur, Bhattacharyya et al..$^{13}$ report on $11 \%$ patient mortality.

Matejčić et al. ${ }^{14}$ report on complications during the early postoperative period, including deep venous thrombosis (8\%), wound infection (1.7\%), and lethal pulmonary embolism in two of $378(0.52 \%)$ patients, stating that operative treatment combined with a well planned rehabilitation program has great advantages and has been recognized as the treatment of choice.

The optimal treatment for Vancouver type B fractures is controversial. Based on the widely accepted Vancouver classification, type B fractures represent approximately $80 \%$ of all cases. ORIF of periprosthetic femur fractures is recommended where the stem is thought to be well fixed; some authors are of the opinion that revision arthroplasty would be a more appropriate option. This highlights the importance of intraoperative testing for component stability ${ }^{11,12,15}$.

According to the guideline for fractures around a well-fixed stem (Vancouver B1 fractures) in normal bone, the mainstay of operative treatment is ORIF. This can be effectively accomplished with various implants such as cerclage wire, DC or LCP, and bone strut allograft. Cables and non-locking screws can be used for fixation in good quality bone and simple fracture patterns, whereas locking screws should be used in patients with poor bone stock ${ }^{7,11,12}$. Dehghan et al. ${ }^{16}$ suggest that the Vancouver B1 fracture is the only type that can be successfully operated on without a stem revision, which can be treated with an adequate open reduction and internal fixation with LCP system. In a multicentre study, Haddad et al. ${ }^{17}$ reviewed 40 patients with a fracture around a well-fixed femoral stem (B1) in which the stem was not revised but was managed by a plate and cortical struts. Union occurred in $98 \%$ of the fractures and the authors suggest that cortical strut grafts should be routinely used.

In addition to locking plates, some periprosthetic fractures with simple fracture patterns (transverse or short oblique) and no comminution are best treated by absolute stability via a dynamic compression plate $(\mathrm{DCP})^{7,11,12}$.

In our study, we used multiple wire cerclages for type B1 fractures and had a satisfactory score results with bone healing of fractures.

If the stem is loose, as in type B2 fractures, revision with a long-stem femoral component is preferable. This approach of the Vancouver protocol does not only restore stability to the femoral component, but also provides reliable intramedullary fixation of the fracture ${ }^{7,18,19}$.

Revision surgery using uncemented long stem, with or without additional fracture fixation (cerclage wires, cortical strut allografts), appears to offer the most reliable outcome. Cement-in-cement revision using a long-stem prosthesis is feasible in elderly patients with a well-fixed cement mantle ${ }^{19,20}$.

Revision arthroplasty is the treatment of choice for type B3 fracture patterns ${ }^{11,18-20}$. It is important that the implant obtains adequate distal fixation, provides axial and rotation stability, as proximal bone usually does not provide enough support; sometimes, strut grafts and fixation with cerclage wires are used for additional stability.

Springer et al. ${ }^{20}$ report results in 42 patients with type B2 and type B3 fractures treated with long-stem prosthesis, with a mean follow-up of 68 months. Six patients underwent revision for loosening, nonunion, and dislocation. Two cases were infected. Despite the 
presence of complications, they achieved good success of treatment with $60 \%$ of healed fractures. High union rates are also reported by O'Shea et al. ${ }^{19}$ who treated 10 type B2 fractures and 14 type B3 fractures with uncemented stem implant and used cortical strut grafts in 9 cases; union occurred in 20 of 22 patients.

Bone graft potentially improves fracture healing and stability, restores bone stock, and has been applied to all types of periprosthetic femoral fracture. Autogenous bone graft is osteoconductive and osteoinductive, and it provides osteogenic bone cells $\mathrm{s}^{7,12,17}$.

Bone infection is a major problem in orthopedics, which can be treated by various methods, but the results may or may not be successful. Bone infection (osteomyelitis) further complicates the problem of fracture and changes guidelines for the treatment of fractures. Therapeutic options include retention of the implant for fixation of fractures, the possibility to administer appropriate therapy that will include suppressive antibiotic treatment and negative-pressure wound therapy, or removal of implant in combination with bracing or bone traction; later on, reimplantation of implants may be considered $\mathrm{d}^{7,11,12}$.

\section{Conclusion}

The treatment of periprosthetic femoral fractures presents a challenge to orthopedic surgeons, as it requires expertise in the treatment process relating to proper assessment of the patient's general condition, and stability of the turn of the prosthesis, as well as the quality of the bone in order to implement an optimal method of treatment. Therapeutically, the treatment protocol recommended by the Vancouver classification is good and it gives clear guidance on how to treat fracture in the given situation.

In our work, we used techniques and implants that are not recommended by Vancouver classification, but which were appropriate for a given case based on our experience and estimates and with which we were able to treat the fracture. It refers primarily to the use of osteosynthesis plate and screws or wire cerclages at a loosened stem.

Today's gold standard for surgical treatment is the use of plates and screws (DCP or LCP) and revision of stem with long cementless revision stem, depending on the subtype of fracture and condition and looseness of the implant.
We believe that prevention of fractures is an important factor that could reduce their increasing incidence by acting upon the risk factors (surgical technique, implant biomechanics, $\mathrm{x}$-rays to check osteolysis) and addressing the problems of endoprosthesis (revision) before fracture.

\section{Acknowledgment}

The authors express their thanks to the physicians from the Clinical Department of Orthopedics, Clinical Center of Montenegro, for their support in this study.

\section{References}

1. Berry DJ. Management of periprosthetic fractures: the hip. J Arthroplasty. 2002;17(4 Suppl 1):11-3.

2. Kavanagh BF. Femoral fractures associated with total hip arthroplasty. Orthop Clin North Am. 1992;23:249-57.

3. Lowenhielm G, Hansson LI, Karrholm J. Fracture of the lower extremity after total hip replacement. Arch Orthop Trauma Surg. 1989;108:141-3.

4. Horwitz IB, Lenobel MI. Artificial hip prosthesis in acute and nonunion fractures of the femoral neck: follow-up study of seventy cases. J Am Med Assoc. 1954;155(6):564-7.

5. Lindahl H, Malchau H, Herberts P, Garellick G. Periprosthetic femoral fractures: classification and demographics of 1049 periprosthetic femoral fractures from the Swedish National Hip Arthroplasty Register. J Arthroplasty. 2005;20:857-65.

6. Duncan CP, Masri BA. Fractures of the femur after hip replacement. Instr Course Lect. 1995;44:293-304.

7. Campbell P, McWilliams TG. Periprosthetic femoral fractures. Curr Orthop. 2008;16:126-32.

8. Park MS, Lim YJ, Chung WC, Ham DH, Lee SH. Management of periprosthetic femur fractures treated with distal fixation using a modular femoral stem using an anterolateral approach. J Arthroplasty. 2009;8:1270-6. doi: 10.1016/j. arth.2009.07.013

9. Zuurmond RG, van Wijhe W, van Raay JJ, Bulstra SK. High incidence of complications and poor clinical outcome in the operative treatment of periprosthetic femoral fractures: an analysis of 71 cases. Injury. 2010;41(6):629-33.

10. Chakravarthy J, Bansal R, Cooper J. Locking plate osteosynthesis for Vancouver type B1 and type $\mathrm{C}$ periprosthetic fractures of femur: a report on 12 patients. Injury. 2007;38(6): 725-33.

11. Marsland D, Mears SC. A review of periprosthetic femoral fractures associated with total hip arthroplasty. Geriatr Orthop Surg Rehabil. 2012;3:107-20.

12. Lewallen DG, Berry DJ. Periprosthetic fracture of the femur after total hip arthroplasty: treatment and results to date. Instr Course Lect. 1998;47:243-9. 
13. Bhattacharyya T, Chang D, Meigs JB, Estok DM $2^{\text {nd }}$, Malchau $\mathrm{H}$. Mortality after periprosthetic fracture of the femur. J Bone Joint Surg Am. 2007;89:2658-62.

14. Matejčić A, Bekavac-Bešlin M, Mihovil I, Tomljenović M, Krolo I, Vučetić B. Fractures of the proximal femur in the elderly. Acta Clin Croat. 2002;41(1):15-23.

15. Corten K, Vanrykel F, Bellemans J, et al. An algorithm for the surgical treatment of periprosthetic fractures of the femur around a well-fixed femoral component. J Bone Joint Surg Br. 2009;91:1424-30.

16. Dehghan N, McKee MD, Nauth A, et al. Surgical fixation of Vancouver type B1 periprosthetic femur fractures: a systematic review. J Orthop Trauma. 2014;28:721-7.

17. Haddad FS, Duncan CP, Berry DJ, et al. Periprosthetic femoral fractures around well-fixed implants: use of cortical onlay al- lografts with or without a plate. J Bone Joint Surg Am. 2002;84-A:945-50.

18. Mulay S, Hassan T, Birtwistle S, Power R. Management of types B2 and B3 femoral periprosthetic fractures by a tapered, fluted, and distally fixed stem. J Arthroplasty. 2005;20(6): 751-6.

19. O'Shea K, Quinlan JF, Kutty S, Mulcahy D, Brady OH. The use of uncemented extensively porous-coated femoral components in the management of Vancouver B2 and B3 periprosthetic femoral fractures. J Bone Joint Surg Br. 2005;87(12): 1617-21.

20. Springer BD, Berry DJ, Lewallen DG. Treatment of periprosthetic femoral fractures following total hip arthroplasty with femoral component revision. J Bone Joint Surg Am. 2003;85 (11):2156-62.

\title{
LIJEČENJE PERIPROTETSKIH PRIJELOMA BEDRENE KOSTI NAKON TOTALNE PROTEZE KUKA KOD VANKUVERSKOG TIPA B
}

\author{
N. Bulatovic, M. Kezunovic, Č. Vučetić, N. Abdić, I. Benčić i T. Čengić
}

Incidencija periprotetskih prijeloma bedrene kosti kod totalne proteze kuka (TPK) je u stalnom porastu u posljednja dva desetljeća i kreće se u opsegu od 0,1\%-2,1\%. Ovi su prijelomi karakteristični za osobe starije životne dobi s prisutnim kroničnim bolestima, često slabijom kvalitetom kosti, a samo liječenje je kirurški složeno i zahtjevno te praćeno nizom komplikacija. Ova retrospektivna studija je obuhvatila 23 bolesnika liječenih u razdoblju od siječnja 2004. do prosinca 2015. godine. Srednje vrijeme praćenja je bilo 14,5 (od 9 do 25) mjeseci. Bilo je 17 bolesnika s cementnom i šest s bescementnom TPK. U rješavanju prijeloma rabili smo različite tehnike: uporabu žičanih serklaža, DC ploče, LCP sustava i dugog revizijskog stema. Za podjelu prijeloma služili smo se Vankuverskom klasifikacijom po Duncanu i Masriju. Za kliničku evaluaciju rabili smo modificirani Merle d'Aubignéov sustav bodova i pratili komplikacije tijekom liječenja. Cilj je prikazati rezultate liječenja periprotetskih femoralnih prijeloma tipa B nakon uporabe različitih operativnih tehnika i implantata u rješavanju ovoga tipa prijeloma. Prema Vankuverskoj klasifikaciji unutar tipa B zabilježena je podklasifikacija na B1 s $10(43,47 \%)$ bolesnika, B2 s $10(43,47 \%)$ bolesnika i B3 s $3(13,04 \%)$ bolesnika. Distribucija bolesnika prema spolu bila je: $8(34,8 \%)$ muškog spola i $15(65,2 \%)$ ženskog spola. Srednja životna dob ispitanika bila je 59,5 (47-86) godina. Od ukupnog broja ispitanika bilo ih je $12(52,2 \%)$ s prijelomom na lijevoj i $11(47,8 \%)$ na desnoj strani. Srednje vrijeme hospitalizacije je bilo 16 (9-26) dana. Primjenom Merle d'Aubignéova sustava bodova kod 10 bolesnika s prijelomom B1 dobivena je srednja ocjena od 11,5 bodova (loš rezultat). Kod 10 bolesnika s prijelomom B2 dobivena je srednja ocjena od 10.6 bodova (loš rezultat). Kod 3 ispitanika s prijelomom B3 dobivena je srednja ocjena od 12 bodova (dovoljan rezultat). Vankuverska klasifikacija i protokol liječenja za periprotetske femoralne prijelome kod TPK je opće prihvaćena i daje sigurne smjernice u donošenju odluke pri liječenju, odnosno korištenju implantata. U našem radu rabili smo različite implantate, žičane serklaže, DC ploču, LCP sustav i dugi revizijski stem u kiruškom liječenju ovoga tipa prijeloma. U određenom broju slučajeva primijenili smo kirurške tehnike odnosno implantate koje ne preporučuje Vankuverski protokol; u ovim slučajevima zabilježen je izostanak cijeljenja kosti, pomicanje i lomljenje implantata, što je rezultiralo nezadovoljavajućim ishodom liječenja.

Ključne riječi: Totalna proteza kuka; Periprotetski prijelom femura; Vankuverska klasifikacija; Komplikacije 